\title{
ABOUT THE SERIES EDITORS
}

Chance W. Lewis is the Carol Grotnes Belk Distinguished Professor and Endowed Chair of Urban Education at The University of North Carolina at Charlotte. Dr. Lewis teaches urban education graduate courses in the College of Education and coordinates its urban education doctoral program division. He also serves as the Executive Director of The University of North Carolina at Charlotte Urban Research and Policy Collaborative.

Over the years, Dr. Lewis has held a number of positions in K-12 and higher education settings. From 2006 to 2011, he served as the Houston Endowed Chair and Associate Professor of Urban Education in the College of Education at Texas A\&M University. During that time, Dr. Lewis also served as the Co-director of the Center for Urban School Partnerships. From 2001 to 2006, he was an assistant professor of teacher education at Colorado State University, and, from 1994 to 1998, he was a business education teacher in East Baton Rouge Parish Schools in Baton Rouge, Louisiana, where he earned teacher of the year honors in 1997.

Dr. Lewis has over 100 publications, including $70+$ refereed journal articles in some of the leading academic journals in urban education and teacher education. He has received over $\$ 6$ million in grants and contracts from government agencies and private corporations. To date, Dr. Lewis has authored/coauthored/coedited 18 books: White Teachers/Diverse Classrooms: A Guide for Building Inclusive Schools, Eliminating Racism and Promoting High Expectations (Stylus, 2006); The Dilemmas of Being an African American Male in the New Millennium (Infinity, 2008); An Educator's Guide to Working with African American Students: Strategies for Promoting Academic Success (Infinity, 2009); Transforming Teacher Education: What Went Wrong with Teacher Training and How We Can Fix It (Stylus, 2010); White Teachers/Diverse classrooms: Creating Inclusive schools, Building on Students' Diversity and Providing True Educational Equity [2nd Ed.] (Stylus, 2011); Yes We Can!: Improving Urban Schools through Innovative Educational Reform (Information Age, 2011); African Americans in Urban Schools: Critical Issues and Solutions for Achievement (Peter Lang, 2012); Black Males in Postsecondary Education: Examining their Experiences in Diverse Institutional Contexts (Information Age, 2012); Improving Urban Schools: Equity and Access in K-16 STEM Education (Information Age, 2013); Black Male Teachers: Diversifying the United States' Teacher Workforce (Emerald Publishing, 2013); and An Educator's Guide to Working with African American Students: Strategies for Promoting Academic Success [2nd Edition] (LEC 
Press, 2013); African American Male Students in PreK-12 Contexts: Implications for Research, Policy \& Practice (Emerald, 2014); Teacher Education \& Black Communities: Implications for Access, Equity and Achievement (Information Age, 2014); Autoethnography as a Lighthouse: Illuminating Race, Research and the Politics of Schooling (Information Age, 2015); Priorities of the Professoriate: Engaging Multiple Forms of Scholarship across Rural and Urban Institutions (Information Age, 2015); High School to College Research Studies (University Press of America, 2015); and Reaching the Mountaintop of the Academy: Personal Narratives, Advice and Strategies from Black Distinguished and Endowed Professors (Information Age, 2015); and An Educator's Guide to Working with African American Students (LEC Press, 2016).

Because of Dr. Lewis's scholastic achievements, over 100 school districts and universities across the United States and Canada have contracted his services to provide professional development and conduct program evaluations. His achievements have been recognized throughout the country in the form of numerous awards, citations, and recognitions for his work.

James L. Moore III is the EHE Distinguished Professor of Urban Education and executive director of the Todd Anthony Bell National Resource Center on the African American Male at The Ohio State University. From 2011 to 2015, he served as the associate provost for Diversity and Inclusion, where he managed numerous programs. He has also held other higher education positions at both University of South Carolina and Virginia Polytechnic Institute and State University.

Dr. Moore has biographies listed in Outstanding Young Men in America (1998 edition), Academic Keys Who's Who in Education (2003 edition), Manchester Who's Who Among Professionals in Counseling and Development (2005/2006 edition), Prestige International Who's Who Registries of Outstanding Professionals (2007 edition), and Who's Who in Black Columbus (2008, 2009, 2010, 2011, 2012, 2013, 2014, and 2015 editions). He is the recipient of Brothers of the Academy's National Junior Scholar Award (2003), The Ohio State University's College of Education Distinguished Scholar Award (2004), North Central Association for Counselor Education and Supervision's Research Award (2004), Ohio School Counselor Association's Research Award (2004), American Educational Research Association's Division E Early Career Award in Counseling (2005), Ohio School Counselors Association's George E. Hill Counselor Educator Award (2005), Counselors for Social Justice's Ohana Award (2006), Phi Delta Kappa's Emerging Leaders Award (2007-2008), American Educational Research Association's Distinguished Scholar Award in Counseling-Division E (2008), National Association for Gifted Children's Early Scholar Award (2009), Institute for School-Based Family Counseling's Outstanding Contributions to School-Based Family Counseling (2009), National Association for 
Multicultural Education's Carl A. Grant Multicultural Research Award (2009), National Alliance of Black School Educators' W. E. B. Du Bois Higher Education Award (2010), Ohio State Black Graduate and Professional Student Caucus' Lawrence Williamson Jr. Service Award (2011), TheBlackManCan.org's Black Man Can Award (2012), American College Personnel Association's Standing Committee on Men and Masculinities Outstanding Research Award (2013), Columbus Leaders Award (2013), HBCU Digest's Genesis Scholar Award (2014), American College Personnel Association's Standing Committee on Men and Masculinities Outstanding Men's Program Award (2014), American Counseling Association Fellow Status (2014), Iota Phi Theta Fraternity, Inc.'s Who Care Community Service/Humanitarian Award (2015), Ohio School Counselor Association's Counselor Educator of the Year Award (2015), National Association for Gifted Children Special Population Network's Gifted and Special Population Award (2015), American Educational Research Association's Scholars of Color Mid-Career Contribution Award (2017), American Educational Research Association's Multicultural/Multiethnic Education Special Interest Group Dr. Carlos J. Vallejo Memorial Award for Lifetime Scholarship (2017) and is an inducted member in numerous professional and honor societies, such as Alpha Kappa Mu, Phi Kappa Phi, Phi Delta Kappa, Kappa Delta Pi, and Chi Sigma Iota.

Throughout the United States, Dr. Moore is a highly sought-after speaker. $\mathrm{He}$ has appeared in numerous documentaries, television and radio programs, and print media publications (i.e., newspapers, magazines, etc.). He has also frequently served as an education consultant and evaluator for a variety of school systems, state education departments, universities, and nonprofit agencies around the country. 